\title{
How metformin affects various malignancies by means of microRNAs: a brief review
}

\author{
Nahid Alimoradi, Negar Firouzabadi* (i) and Reihaneh Fatehi
}

\begin{abstract}
Metformin known as the first-line orally prescribed drug for lowering blood glucose in type II diabetes (T2DM) has recently found various therapeutic applications including in cancer. Metformin has been studied for its influences in prevention and treatment of cancer through multiple mechanisms such as microRNA (miR) regulation. Alteration in the expression of miRs by metformin may play an important role in the treatment of various cancers. MiRs are singlestranded RNAs that are involved in gene regulation. By binding to the $3^{\prime} U T R$ of target mRNAs, miRs influence protein levels. Irregularities in the expression of miRs that control the expression of oncogenes and tumor suppressor genes are associated with the onset and progression of cancer. Metformin may possess an effect on tumor prevention and progression by modifying miR expression and downstream pathways. Here, we summarize the effect of metformin on different types of cancer by regulating the expression of various miRs and the associated downstream molecules.
\end{abstract}

Keywords: Metformin, MicroRNAs, Cancer, AMPK, Biomarker, Mechanism of action

\section{Introduction}

Metformin is a potent glucose-lowering agent with a biguanide structure that is effective in the treatment of type II diabetes (T2DM). Metformin adjusts cellular energy metabolism through inducing AMP-activated protein kinase (AMPK), an important metabolic sensor that is activated under cellular stress conditions and limits energy consumption by affecting ATP production and consumption $[1,2]$.

There is ample evidence that metformin can reduce the risk of various types of malignancies [3, 4]. However, there are still unresolved questions about the accurate mechanism of metformin in the treatment and prevention of cancer. One of the most well-known mechanisms of metformin as an anticancer drug is linked to the inhibition of the mammalian target of rapamycin complex 1 (mTORC1) through AMPK activation, directly and indirectly [4]. Furthermore, reported studies have shown

*Correspondence: nfirouzabadi@yahoo.com; Firouzabadi@sums.ac.ir Department of Pharmacology and Toxicology, School of Pharmacy, Shiraz University of Medical Sciences, Shiraz, Iran that the effects of metformin on different type of cancers may be mediated via AMPK-dependent and AMPKindependent mechanisms and through regulation of the mitogen-activated protein kinase (MAPK), nuclear factor kappa B (NF-kB), protein kinase B [5] and mTOR signaling pathways $[3,6,7]$.

MicroRNAs (miRs) are small single-stranded and noncoding RNAs that are approximately 22 base pair in length [8]. MiRs regulate the expression of genes posttranscriptionally by binding to the untranslated region $3^{\prime}$ ( $3^{\prime} \mathrm{UTR}$ ) of their messenger RNA (mRNA). Coupling of miRs to their target mRNA sequences leads to cleavage or repression of their translations $[9,10]$. The discovery of new molecular mechanisms suggests that miRs can play a fundamental role in prognosis and diagnosis of cancer. MiRs act as important mediators in most cellular processes. Therefore, knowledge of the effective miRs and their mechanisms of action is essential for a more accurate conception and management of cancer [11]. Here, we discuss the role of metformin in regulating several signaling pathways involved in different types of cancer, which are associated with the regulation of numerous miRs, as shown in Table 1 and Fig. 1. 
Table 1 Examples of miRNAs modulated by metformin in cancers and their putative mRNA targets

\begin{tabular}{|c|c|c|c|c|}
\hline Cancer & miRNAs & $\begin{array}{l}\text { Drug's effect on } \\
\text { miRNAs }\end{array}$ & Putative mRNA(s) targets & References \\
\hline Breast cancer & $\begin{array}{l}\text { miR-27b } \\
\text { miR-26a } \\
\text { miR-21-5p } \\
\text { miR-21 } \\
\text { miR-155 } \\
\text { miR-708 } \\
\text { miR-200c }\end{array}$ & $\begin{array}{l}\text { Up } \\
\text { Up } \\
\text { Down } \\
\text { Up } \\
\text { Down } \\
\text { Down } \\
\text { Up }\end{array}$ & $\begin{array}{l}\text { ENPP1 } \\
\text { PTEN, MCL-1, EZH2, E2F3 \& MTDH } \\
\text { Sestrin-1 \& CAB39L } \\
\text { Foxo-1 } \\
\text { Foxo-3 } \\
\text { CD47 } \\
\text { AKT2 and BCl-2 }\end{array}$ & $\begin{array}{l}{[14]} \\
{[23]} \\
{[28]} \\
{[29]} \\
{[29]} \\
{[35]} \\
{[37]}\end{array}$ \\
\hline Cervical cancer & miR-142-3p & Up & HMGA2 & {$[40]$} \\
\hline Cholangiocarcinoma & miR-302 & Up & Rb, cyclin D1\& Cdk4 & {$[48]$} \\
\hline Colorectal cancer & $\begin{array}{l}\text { miR-21 } \\
\text { miR-200 family } \\
\text { miR-34a }\end{array}$ & $\begin{array}{l}\text { Down } \\
\text { Up } \\
\text { Up }\end{array}$ & $\begin{array}{l}\text { Spry2 } \\
\text { ZEB } \\
\text { SNAIL1 }\end{array}$ & $\begin{array}{l}{[54]} \\
{[61]} \\
{[61]}\end{array}$ \\
\hline Endometrial Hyperplasia & $\begin{array}{l}\text { let-7 } \\
\text { miR-144 }\end{array}$ & $\begin{array}{l}\text { Up } \\
\text { Up }\end{array}$ & $\begin{array}{l}\text { c-Myc, HMGA2 \& Imp3 } \\
\text { EZH2 }\end{array}$ & $\begin{array}{l}{[47]} \\
{[85]}\end{array}$ \\
\hline Gallbladder cancer & miR-675-5p & Up & - & [89] \\
\hline Gastric cancer & $\begin{array}{l}\text { miR-15a } \\
\text { miR-128 } \\
\text { miR-192 } \\
\text { miR-194 }\end{array}$ & $\begin{array}{l}\text { Up } \\
\text { Up } \\
\text { Up } \\
\text { Up }\end{array}$ & $\begin{array}{l}\text { Bmi-1 } \\
\text { Bmi-1 } \\
\text { Bmi-1 } \\
\text { Bmi-1 }\end{array}$ & $\begin{array}{l}{[96]} \\
{[96]} \\
{[96]} \\
{[96]}\end{array}$ \\
\hline Hypo pharyngeal Carcinoma & miR-21-5p & Down & PDCD4 & {$[101]$} \\
\hline Non-small-cell lung Cancer & $\begin{array}{l}\text { miR-7 } \\
\text { miR-381 } \\
\text { miR-107 }\end{array}$ & $\begin{array}{l}\text { Up } \\
\text { Up } \\
\text { Down }\end{array}$ & $\begin{array}{l}\mathrm{BCl}-2 \\
\text { YAP } \\
\text { Eomes }\end{array}$ & $\begin{array}{l}{[107]} \\
{[112]} \\
{[115]}\end{array}$ \\
\hline Osteosarcoma & miR-570-3p & Up & LCMR1 and ATG12 & [119] \\
\hline Ovarian cancer & $\begin{array}{l}\text { let-7 } \\
\text { miR-3127-5p }\end{array}$ & $\begin{array}{l}\text { Up } \\
\text { Up }\end{array}$ & $\begin{array}{l}\text { c-Myc, HMGA2 \& Imp3 } \\
\text { LC3 }\end{array}$ & $\begin{array}{l}{[47]} \\
{[123]}\end{array}$ \\
\hline Pancreatic cancer & $\begin{array}{l}\text { miR-150 } \\
\text { miR-210-5p } \\
\text { miR-221 } \\
\text { miR-200a-3p }\end{array}$ & $\begin{array}{l}\text { Up } \\
\text { Up } \\
\text { Down } \\
\text { Down }\end{array}$ & $\begin{array}{l}\text { MUC4 } \\
\text { PFKFB2 } \\
\text { P27 } \\
-\end{array}$ & $\begin{array}{l}{[73]} \\
{[136]} \\
{[141]} \\
{[149]}\end{array}$ \\
\hline Prostate cancer & miR-708 & Up & NNAT & {$[150]$} \\
\hline Renal cell carcinoma & $\begin{array}{l}\text { miR-21 } \\
\text { miR-34a }\end{array}$ & $\begin{array}{l}\text { Down } \\
\text { Up }\end{array}$ & $\begin{array}{l}\text { PTEN } \\
\text { cyclin D1 }\end{array}$ & $\begin{array}{l}{[155]} \\
{[159]}\end{array}$ \\
\hline Skin cancer & $\begin{array}{l}\text { miR-21 } \\
\text { miR-192-5p } \\
\text { miR-584-3p }\end{array}$ & $\begin{array}{l}\text { Down } \\
\text { Up } \\
\text { Up }\end{array}$ & $\begin{array}{l}\text { PTEN } \\
\text { EFEMP1 } \\
\text { SCAMP3 }\end{array}$ & $\begin{array}{l}{[166]} \\
{[175]} \\
{[175]}\end{array}$ \\
\hline
\end{tabular}

\section{Breast cancer}

\section{MiR-27b}

Expression of miR-27b is among the various miRs that are influenced by metformin. MiR-27b that is a tissue/ cellular miR, does not have a constant behavior in cancer development and its action differs from type to type of cancer. While it plays an oncogenic role in some types of breast cancer, it has a tumor-suppressor role in luminaltype breast cancer and prevents side-population cell (SP fraction) generation [12-14]. Ectonucleotide pyrophosphatase/phosphodiesterase family member 1 (ENPP1), that is negatively modulated by metformin, is up-regulated in this type of breast cancer. It was found that $3^{\prime}$ UTR of ENPP1 has a binding site for miR-27b and is a direct target of miR-27b $[14,15]$. ENPP1 has the ability to induce SP fraction generation which is involved in the process of drug resistance and tumor genesis by altering cell surface efflux pumps such as ATP-binding cassette super-family G member 2 (ABCG2) and $26 \mathrm{~S}$ proteasome activity $[14,16]$. Metformin reduces SP fraction in breast cancer cells by up-regulating miR-27b [14].

\section{MiR-26a}

Decreased expression of circulating miR-26 in several cancers such as breast cancer indicates the tumor-suppressing role of miR-26 [17-22]. On the other hand, increased expression of miR-26a by metformin, has shown to significantly inhibit cell viability in breast cancer cells. MiR-26a directly targets several anti-apoptotic proteins, such as E2F Transcription Factor 3 (E2F3), myeloid cell leukaemia-1 (Mcl-1), metadherin (MTDH), enhancer of zeste homolog 2 (EZH2), and phosphatase 


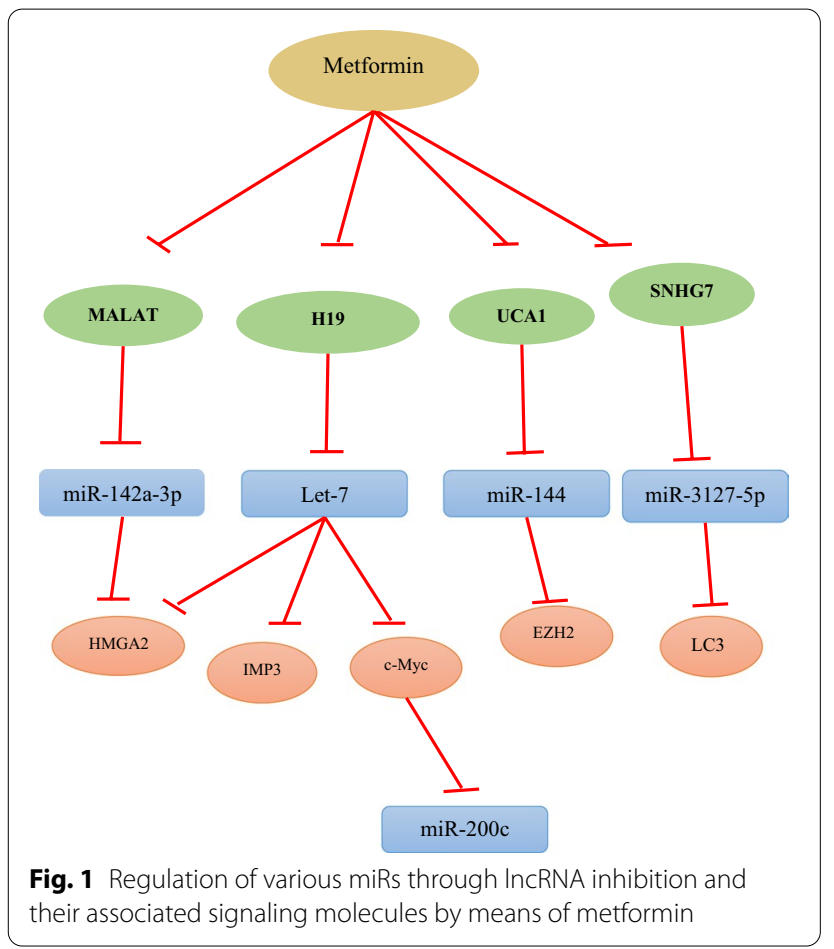

and tensin homolog (PTEN) which are up-regulated in breast cancer. Over-expression of miR-26a by metformin down-regulates these targets in breast cancer cells [23-25].

\section{MiR-21 and miR-155}

MiR-21 is one of the prominent up-regulated oncomiRs in many types of cancers such as breast cancer cells [26, 27]. Metformin inhibits proliferation and metastasis via down-regulation of miR-21-5p in breast cancer cell lines. Evidences have also shown a decrease in miR-21-5p levels in serum of patients with a history of breast cancer who were treated with metformin. MiR-21-5P suppresses the expression of calcium-binding protein 39-like (CAB39L) and Sestrin-1, the activators of AMPK, thus causing decreasing AMPK activation and increasing mTOR signaling. These results suggest that metformin activates AMPK and inhibits mTOR in breast cancer by inhibiting miR-21-5p [28].

The results of another study which has been carried out in various types of breast cancer cell lines with different hormonal backgrounds including MCF-7, MDAMB-231, and T47D indicated that metformin treatment significantly inhibits breast cancer metastasis, through down-regulation of two oncogenic circulating miRs, miR-21 and miR-155. Aberrant expression levels of these two miRs are linked to invasive and metastatic properties of cancerous cells [29, 30]. MiR-21 and miR-155, both target forkhead box class $\mathrm{O} 3 \mathrm{a}$ (FOXO3a) in breast cancer which acts as a tumor suppressor [31, 32]. It has been shown that metformin is associated with AMPK and FOXO3a activation in MCF-7 breast cancer cells [33].

\section{MiR-708}

A study on breast cancer stem cells conveyed that metformin could indirectly affect immune-related genes such as cluster of differentiation 47 (CD47) that are involved in resistance to chemotherapy. Indeed, metformin treatment could cause the restoration of miR-708 that is a cellular/tissue miR and decrease the expression level of CD47 which consequently results in chemo-sensitivity in breast cancer. CD47 is over-expressed in various cancers and provides inhibitory actions when it binds to the signal regulatory protein alpha $(\mathrm{SIRP} \alpha)$ receptor, which is expressed on macrophages and prevents phagocytosis $[34,35]$.

\section{MiR-200c}

MiR-200c is a circulating miR with the potential as a biomarker for breast cancer prognosis [36]. Metformin inhibits metastatic process and proliferation in breast cancer cells by reducing the expression of cellular Myb (c-Myc). c-Myc can bind to the miR-200c promoter leading to its inhibition. Metformin inhibits c-Myc causing $\mathrm{miR}-200 \mathrm{c}$ up-regulation. Up-regulation of miR-200c is associated with a decrease in the amount of AKT2 and B-cell lymphoma $2(\mathrm{Bcl}-2)$ which are directly targeted by miR-200c [37].

\section{Cervical cancer}

\section{MiR-142}

MiR-142-3p, a tissue/cellular miR with a tumor suppressive role, which is down-regulated in several types of cancer may serve as a biomarker for diagnosis and prognosis of specific malignancies [38, 39]. MiR-142 directly targets high-mobility group protein A2 (HMGA2) which is an oncogene. By this means, it inhibits the proliferation and invasion of cervical cancer cells [40]. Based on previous reports, HMGA2 plays a role in epithelial-mesenchymal transition (EMT) and is over-expressed in several cancers and is responsible for the invasive and metastatic behaviors of cancer cells [41-43]. Besides, metastasis-associated lung adenocarcinoma transcript 1 (MALAT1) which is a long noncoding RNA (lncRNA), is elevated in various cancer types such as osteosarcoma, breast, prostate and cervical cancer [40, 44-46]. MALAT1 binds to miR$142-3 p$ like a sponge and prevents its inhibitory effect on HMGA2. Metformin may inhibit MALAT1 expression by affecting DNA methylation of the MALAT1 promoter. Inhibition of the formation of MALAT1/miR-142-3p complex disrupts HMGA2 expression, and thus the free 
form of miR-142-3p is increased [40, 47]. In this manner, metformin exerts its anticancer actions by targeting miR142 indirectly.

\section{Cholangiocarcinoma}

\section{MiR-302}

In a study conducted by Fujimori et al., the anti-proliferative effects of metformin on the cholangiocarcinoma cell line and tumor tissue and the expression of a number of miRs were analyzed. It was observed that along with the inhibitory effects of metformin on the proliferation of these cells and cell cycle (G0 to G1), the expression of miR-302b,c increased and cell cycle regulator proteins such as retinoblastoma (Rb), cyclin D1, and Cdk4 decreased [48, 49]. Complexes of cyclin-dependent kinases (CDKs) such as CDK4 and CDK6 with cyclin D1 are required for $\mathrm{G} 1$ phase progression [50]. Various studies have shown that metformin has the ability to down regulate cyclin D1 in various cancer cell lines [51-53]. It is possible that metformin mediates cell cycle regulators (cyclin D1, CDK4, and phosphorylated Rb) by overexpressing miR-302 in cholangiocarcinoma.

\section{Colorectal cancer}

\section{MiR-21}

A study regarding treatment of colon cancer cells with metformin indicated that metformin increases the expression level of Sprouty2 (Spry2), and PTEN by inhibiting the expression of miR-21 which in turn represses cell growth [54, 55]. Over-expression of circulating miR21 is related to disease progression in colorectal cancer [56]. Studies have shown that up-regulation of miR-21 is associated with down-regulation of Spry2 in certain types of cancer. Thus, Spry2 could be described as a direct target of miR-21 [54, 55]. Spry2 is identified as a negative regulator of receptor tyrosine kinases (RTKs) which inhibit extracellular signal-regulated kinase (ERK) /MAP kinase pathways $[55,57,58]$. In addition, Spry2 increases the level of PTEN that in turn alleviates the activity of Akt leading to inhibition of mTORC1 $[55,59,60]$.

\section{MiR-34a and miR-200 family}

Metformin inhibits the over-expression of classical EMT markers such as SNAIL and zinc finger E-box binding homeobox (ZEB) by potentiating the expression of miR-34a and miR-200 to prevent colorectal cancer progression and/or tumor recurrence [61]. Metformin also exhibits its anti-EMT effects by altering the ratio of E-cadherin, an epithelial marker, to vimentin, a mesenchymal marker [61]. SNAIL and ZEB repress E-cadherin transcription in different ways $[62,63]$. Studies on colorectal cancer suggested that down-regulation of circulating miR-34 and miR-200 family contributes to EMT and metastatic behavior [64-67]. Surprisingly, miR-34a was decreased in metformin treated cells. This action may be related to the inducing effects of metformin on Sirtuin-1 which is involved in the p53-miR-34a-Sirtuin axis and the generation of reactive oxygen species [68]. The results of studies indicate that metformin-induced p53 protein level in wild type p53 cancer cells lead to up-regulation of miR-34a. Induction of miR-34a leads to down-regulation of Sirtuin-1. Sirtuin-1 exhibits oncogenic properties in wild-type p53 cancer cells while acting as a tumor suppressor in mutant p53 cancer cells [76]. These results suggest that the effect of metformin in cancer cells depends on the status of p53. Metformin reduces Sirtuin1 protein levels only in wild type p53 cancer cells but does not affect the Sirtuin 1 protein level in mutant forms of p53 [69, 70]. A well-established in-vitro senescence model treated with metformin has shown that metformin is able to accelerate the onset of stress-induced senescence (SIS), as well as lowering its threshold. It was also found that metformin lowers the threshold of SIS by simultaneous regulation of miR-205 and miR-200 family leading to inhibition of the expression of ZEB1 and ZEB2 transcription factors [71].

\section{Endometrial hyperplasia}

Let-7

Metformin suppresses cell migration and invasion by increasing let-7 expression which is down-regulated in endometrial cancer cells. Let-7 is a well-known tumor suppressor circulating miR that targets mRNAs of oncogenic genes such as c-Myc, HMGA2 and insulin-like growth factor 2 mRNA-binding protein 3 (Imp3) [47, 72]. It is assumed that metformin affects let-7 expression by different mechanisms altering H19/let-7 axis, Lin28/let-7 axis and AMPK phosphorylation. Metformin may also act in a DICER1-dependent manner and apply its tumor suppressing effects [47, 73-76]. MiRs maturation takes place in several stags, from the nucleus to the cytoplasm, by several enzymes among which DICER, an RNase III nuclease, is the last enzyme [77]. H19, a lncRNA, which is elevated in various cancer types, binds to let-7 like a sponge and inhibits its function [78]. Additionally, Lin28, an RNA-binding protein that induces the pluripotency of adult human fibroblast cells and suppresses the production of let-7, is over-expressed in advanced cancers $[79,80]$. Intriguingly, H19 and LIN28 expression is also down-regulated by let-7 [81]. Lin28 prevents the effect of DICER on let- 7 by binding to the pre-let-7 terminal loop and induces pre-let- 7 terminal uridylation by TUTase 4 (TUT4), a uridylyl transferase. In this way, DICER cannot remove this uridylated domain and convert pre-let-7 to the mature form of let-7, thus it negatively regulates let-7 expression [82, 83]. Lin28 indirectly increases H19 
expression through inhibition of let-7. In contrast, H19 indirectly increases Lin 28 levels by binding to let-7 and depresses its free form. As a result, both inhibit let-7 function through a double-negative feedback loop mechanism [81]. Metformin enhances methylation of H19 promoter and facilitates S-adenosyl-methionine (SAM)dependent methyltransferase by activating $\mathrm{S}$-adenosyl homocysteine hydrolase $(\mathrm{SAHH})$, which is itself inactivated by binding to $\mathrm{H} 19$ [47, 76, 84]. Hence, metformin induces over-expression of let-7 by inhibiting H19 and LIN28 in endometrial cancer.

\section{MiR-144}

Metformin exerts its antitumor effects in endometrial hyperplasia by triggering the expression of miR-144, which is a cellular miR, and active caspase 3 through decreasing the expression level of urothelial cancerassociated 1 (UCA1), an oncogenic lnc RNA [85]. Studies have indicated that decreased miR-144 expression is closely associated with tumor cell proliferation and invasion in various cancers such as endometrial hyperplasia [86]. Following an increase in miR-144, in metformintreated endometrial cancer cell lines, transforming growth factor- $\beta$ (TGF- $\beta$ ) and p-AKT levels also decrease [85]. Disrupted TGF- $\beta$ signaling is associated with endometrial cancer. UCA1 up-regulation demonstrates its tumorigenic role by inducing the expression of TGF- $\beta 1$. Metformin prevents TGF- $\beta 1$ induction by inhibiting UCA1 [87, 88]. Evidence has shown that miR-144 targets $3^{\prime} \mathrm{UTR}$ of Enhancer of zeste homolog 2 (EZH2), a transcriptional repressor, suppresses the expression of EZH2 and inhibits proliferation, migration and invasion in human endometrial cancer cell lines [86].

\section{Gallbladder cancer MiR-675-5p}

A study performed on human gallbladder cancer cell line, revealed that metformin could suppress cell proliferation and tumor growth via regulating various miR expression profiles. In this study, $35 \mathrm{miRs}$ were identified and their expression levels were significantly changed after metformin treatment. Among these miRs, miR-675-5p, a cellular miR, was reported to be correlated with the antitumor effect of metformin. Part of the growth inhibitory effect of metformin could be due to miR-675-5p expression as metformin increased its expression in these cells as well [89]. MiR-675-5p has been characterized as a tumor suppressor in several human cancers. Decreased expression of miR-675-5p in various cancers such as gallbladder cancer, led to enhanced cell growth, proliferation, colony formation, invasion, and migration [89-91].

\section{Gastric cancer}

MiR-15a, miR-128, miR-192 and miR-194

B-lymphoma moloney murine leukemia virus insertion region-1 (Bmi-1) as an oncogene, is involved in selfrenewal and differentiation of stem cells, tumor genesis and metastasis [92, 93]. Bmi-1 over-expression was reported to be closely associated with different malignancies $[94,95]$. Bmi- 1 is the direct target of miR-15a, miR128, miR-192 and miR-194, the tumor suppressor miRs that are up-regulated in human gastric carcinoma cells and tissue samples treated with metformin [96]. Circulating miR-192 is known as a diagnostic and prognostic biomarker in gastric cancer [97]. Metformin as an AMPK activator, inhibits cell migration, invasion and cancer progression by up-regulating these miRs $[98,99]$. Activation of AMPK leads to over-expression of miR-15a, miR-128, miR-192 and miR-194 thus reducing Bmi-1 expression $(96,100)$. In this manner, metformin promotes up-regulation of miRs and performs its anti-tumor effects [96].

\section{Hypo pharyngeal cancer MiR-21-5p}

MiR-21-5p, a circulating miR, is significantly up-regulated in hypo pharyngeal carcinoma. A study concluded that metformin prevents cell proliferation in hypo pharyngeal carcinoma possibly via down-regulation of miR21-5P and up-regulation of programmed cell death protein 4 (PDCD4) [5, 101, 102]. PDCD4 is considered as a tumor suppressor and is correlated with apoptosis in hypo pharyngeal carcinoma cells, which has an inverse correlation with miR-21 expression (103). Studies have demonstrated that the expression of PDCD4 is reduced in several types of cancer cell lines in which miR-21 is over-expressed $[104,105]$. The expression of signal transducer and activator of transcription 3 (STAT3) is activated by miR-21 in EMT. Since, STAT3 is enhanced in PDCD4 knockdown human laryngeal carcinoma cell line, miR-21 may be the downstream molecule of PDCD4 and metformin may inhibit miR-21 through up-regulation of PDCD4 [106].

\section{Non-small-cell lung cancer MiR-7}

Metformin promotes cell apoptosis and inhibits nonsmall cell lung cancer cells growth by stimulating the expression of miR-7 through AMPK dependent mechanism [107]. Several studies have shown that over-expression of miR-7 markedly inhibits growth, migration, and invasion of lung cancer cells, by targeting BCL-2, an anti-apoptotic protein which has the ability to suppress tumorigenicity $[108,109]$. Up-regulation of miR-7 could dramatically arrest the three signaling pathways of AKT/ mTOR, MAPK/Erk, and NF- $k B$ that are involved in the 
formation, growth, apoptosis, invasion, metastasis, and angiogenesis in lung cancer [107]. Based on studies, circulating miR-7 can be considered as a diagnostic biomarker in patients with non-small-cell lung cancer [110, $111]$.

\section{MiR-381}

A new study has shed light on how metformin acts in preventing tumorigenesis and metastasis in non-small cell lung cancer. MiR-381 is a new cellular/tissue miR candidate that is probably involved in non-small cell lung cancer. This miR is reported to be a tumor suppressor and a participant in the miR-381-YAP-Snail signaling axis. Metformin suppresses cell proliferation, invasion, and migration in non-small cell lung cancer cells by regulating this pathway [112]. A previous study suggested that metformin may be able to inhibit the function of Yes kinase-associated protein (YAP) in non-small cell lung cancer by preventing the binding of interferon regulatory factor 1 (IRF-1) and YAP promoter [113]. Yap has a transcriptional activation domain that regulates transcription via occupation of the promotor region of the target genes, thus its inhibition leads to suppression of cell proliferation and progression of apoptosis, thereby limiting tumor size [114]. On the other hand, YAP is able to positively influence snail expression, an important factor in induction of EMT. Snail inhibition leads to E-cadherin up-regulation and disruption of EMT in lung cancer cells. Due to the up-regulation of miR-381 by metformin treatment, the expression of YAP and snail are decreased and EMT is inhibited [112].

\section{MiR-107}

Metformin can regulate $\mathrm{T}$ cell functions in patients with non-small cell lung cancer by reprograming the differentiation of memory stem $\mathrm{T}$ (Tscm) and central memory $\mathrm{T}(\mathrm{Tcm})$ which are subsets of memory CD8 $+\mathrm{T}$ cells. According to a study by Zhang et al., AMPK activation leads to down-regulation of miR-107 which targets Eomesodermin (Eomes). Eomes is an impressive factor in $\mathrm{T}$ cell differentiation. Metformin promotes differentiation of $\mathrm{T}$ cells and inhibits their proliferation and expression of programmed cell death protein (PD-1). PD-1 is an inhibitory receptor which is expressed in exhausted $\mathrm{T}$ cells during cancer [115]. On the other hand, mTOR which is negatively regulated by AMPK activation can reduce Eomes and increase PD-1 expression $(116,117)$. Moreover, miR-107 can inhibit tumor growth and metastasis through targeting brain-derived neurotrophic factor (BDNF)/PI3K/AKT axis in human non-small lung cancer [118]. Hence, metformin may lead to affecting expressions of miR-107 via an AMPK-dependent mechanism.

\section{Osteosarcoma}

\section{MiR-570-3p}

The results obtained from a miR microarray assay in osteosarcoma cells showed that metformin causes demethylation of DNA at the CpG islands of miR-570-3p promoter regions, thus elevating the expression of miR570-3p, a tumor suppressor miR [119]. MiR-570-3p plays an anti-cancer role in various tumors via inhibiting cell proliferation, migration, and invasion [120, 121]. In tissues of osteosarcoma patients, increased expression of miR-570-3p could result in the repression of its target genes translation such as lung cancer metastasis-related protein (LCMR1) and autophagy-related gene 12 (AtG12) which are involved in metastasis and autophagy, respectively, and prevent apoptosis by its ability to directly bind to $3^{\prime} \mathrm{UTR}$ regions [119]. The role of metformin in over-expressing miR-570-3p highlights its potential role in attenuating metastasis and autophagy by means of miR-570-3p.

\section{Ovarian cancer \\ Let-7}

Decreased circulating let-7 expression is an independent prognostic biomarker for ovarian cancer [122]. Metformin suppresses cell migration and invasion by increasing let-7 levels as observed in endometrial cancer [47]. It is assumed that metformin affects let-7 expression by various mechanisms affecting H19/let-7 axis, Lin28/let-7 axis and AMPK phosphorylation. Metformin also acts in a DICER1-dependent manner and applies its anti-tumor effects $[47,73-76]$. The related mechanism is described previously.

\section{MiR-3127-5p}

Resistance to paclitaxel is one of the most prominent causes of failure to chemotherapy in ovarian cancer. Metformin can enhance paclitaxel sensitivity by regulating the expression levels of lncRNA small nucleolar RNA host gene 7 (SNHG7) and miR-3127-5p and impeding the autophagy process in animal models of ovarian cancer and cancer cells. Metformin treatment could abrogate SNHG7 expression. Inhibition of SNHG7 results in overexpression of miR-3127-5p that is considered a direct target of SNHG7 [123]. It is noteworthy that miR3127-5p, a tissue/cellular miR, acts as an autophagy regulator by activating of PI3K/AKT signaling pathway [124]. As a result of miR-3127-5p elevation, a decrease in the protein levels of microtubule -associated proteins $1 \mathrm{~A} / 1 \mathrm{~B}$ light chain 3 -II (LC3II) and Beclin1, as known autophagy markers, as well as an increase in poly (ADP-ribose) polymerase (PARP) protein were observed [123]. LC3-II is a phosphatidylethanolamine conjugate form of LC3 that is 
associated with autophagosome maturation [48]. Besides, LC3 reduction in miR-3127-5p knocked cells may represent LC3 as a predicted target of miR-3127-5p [125]. These data suggest that metformin may influence drug sensitivity in ovarian cancer by attenuating autophagy through SNHG7/miR-3127-5p axis [123].

\section{Pancreatic cancer \\ MiR-150}

Role of metformin in inhibition of cell proliferation in pancreatic cancer cells is assumed to be through up-regulation of miR-150 [73]. MiR-150 is identified as a circulating $\mathrm{miR}$ and a tumor suppressor in many cancers. In patients with pancreatic cancer, decreased blood levels of miR-150 has been observed [126]. MiR-150 inhibits growth and malignant behavior of cancer cells by binding to $3^{\prime} \mathrm{UTR}$ of Mucin 4 (MUC4), a high molecular mass proteoglycan, and down-regulates its expression [127, 128]. In pancreatic cancer cells, miR-150 induces its antiapoptotic effect by reducing c-Myb expression [129]. As a result of c-Myb depletion, its binding to the insulin-like growth factor 1 receptor (IGF-1R) and Bcl-2 promoter decreases. On the other hand transcription and expression of these proteins are inhibited [130]. c-Myb, IGF-1R and Bcl-2 that are over-expressed in pancreatic cancer cells have a controlling role in cell proliferation, apoptosis, and differentiation [129, 131]. Combined treatment of metformin with aspirin suppresses $\mathrm{Bcl}-2$ expression leading to induction of apoptosis in pancreatic cancer cells [132]. On another hand, metformin disrupts interaction between insulin/IGF-1R and G-protein-coupled receptor (GPCR) signaling pathways that have a critical role in the development of pancreatic cancer [133, 134].

\section{MiR-210-5p}

Results of recent studies in human pancreatic cancer cells provide some evidence that the inhibitory effect of metformin on cell viability and expression level of miR210-5p is dependent on glucose state. Metformin induces a more pronounced expression of miR-210-5p in low glucose conditions. Over-expression of miR-210-5p could lead to inhibition of cell activity that is mediated by down-regulation of 6-phosphofructo-2-kinase/fructose2,6-bisphosphatase 2 (PFKFB2), which is characterized as a potential target gene of miR-210-5p. Besides, following the repression of PFKFB2, the glycolysis pathway is inhibited. The activity of two key enzymes in the downstream pathway of glycolysis, phosphofructokinase-1 (PFK1) and lactic acid dehydrogenase is also markedly decreased [135].Thus, it has been suggested that blockade of anaerobic glycolysis could be one of the potential anti-cancer mechanisms of metformin. Due to severe reduction of adenosine triphosphate (ATP) production, cancer cells become more susceptive to metformin-induced stress. Consequently, metformin may be more helpful in nondiabetic patients with pancreatic cancer [136].

\section{MiR-221}

MiR-221 is another known oncomiR which is suppressed by metformin in some cancer cell lines such as human pancreatic cancer cell, human cholangiocarcinoma and endothelial progenitor cells. As a result of this inhibition, termination of the cell cycle in G1 phase occurs [137]. Up-regulation of miR-221 has a major role in proliferation and cell cycle processes. Increased levels of miR-221 have been observed in plasma of patients diagnosed with pancreatic cancer $[138,139]$.

p27, the direct target of miR-221, is a cell-cycle inhibitor which binds to CDK complexes and leads to G1-phase arrest in cancer cells which is negatively modulated by miR-221 [140]. Moreover, p27 expression is increased as a consequence of miR-221 inhibition by metformin in pancreatic cancer cell [141]. Metformin also increases p27 expression through AMPK phosphorylation and causesinhibition of angiogenesis [137]. The reductive and increasing effects of metformin on miR-221 and p27 expression, respectively have also been tangible in studies in diabetic patients [142]. MiR-1 inhibits autophagy by affecting two different pathways: first, by modulating the $\mathrm{p} 27 / \mathrm{CDK} 2 / \mathrm{mTOR}$ axis, secondly, by targeting PTEN, AKT and mTOR signaling axis [143, 144]. Mechanism of metformin in pancreatic cancer may be similar to that in animal models of CCl4-treated hepatocellular carcinoma. Metformin causes down-regulation of miR-221, interfering with AKT expression and its downstream effectors such as S6 and eukaryotic translation initiation factor 4E-binding protein 1 (4EBP1) [145].

\section{MiR-200a}

MiR-200a is known as a tumor suppressor and a plasma/ serum detectable miR. Some studies have shown that over-expression of miR-200a may repress cell proliferation, cell cycle progression and invasion in pancreatic cancer [146-148]. Result of miR microarray assay in pancreatic tumor cells showed that metformin exhibits anticancer effects by down-regulating miR-200a. However the exact mechanism of metformin in this regard is still obscure [149].

\section{Prostate cancer \\ Mir-708}

MiR-708-5p is a circulating miR which acts as a tumorsuppressor by targeting an endoplasmic reticulum (ER) protein neuronatin (NNAT), causing a decrease in intracellular calcium. Metformin treatment dramatically upregulates miR-708-5p expression resulting in inhibition 
of calcium uptake by ER. Decline in intracellular calcium causes ER stress and as a result, cell apoptosis is activated. Thus, NNAT is identified as a novel target of metformin in induction of apoptosis for prostate cancer cells [150-153].

\section{Renal cell carcinoma MiR-21}

Many studies have confirmed the involvement of miR21 in carcinogenesis in kidney cells and targeted PTEN $[154,155]$. The results of a study examining the effect of metformin on renal cell carcinoma originated cells demonstrated the anti-proliferative properties of metformin via miR-21/PTEN/Akt signaling pathway in an AMPK dependent manner in inhibiting cell proliferation [155]. According to a study by Bera et al., regarding the role of miR-21 and its downstream mechanisms, inhibition of PTEN by miR-21 mediates the Akt- inhibitor of nuclear factor kappa-B kinase subunit beta (IKK $\beta$ ) axis and leads to $\mathrm{NF \kappa B}$ activation. As a result of NFKB activation, the expression of cyclin D1 and CDK4 are increased as observed in renal cancer patients [156, 157]. Increased cyclin D1 levels initiates cell cycle progression and cell proliferation by stimulation of CDK4/6 in renal cells [157, 158].

\section{MiR-34a}

A study performed on human renal cancer cell line treated with metformin, indicated that metformin may induce cell cycle arrest by up-regulating the level of miR-34a, decreasing the level of cyclin D1 expression and enhancing cyclin-dependent kinase inhibitor $1 \mathrm{~B}$ (p27Kip1) expression [159]. MiR-34a is considered as a tumor-suppressive miR for its suppressing effects on cell cycle, cell invasion, and cell migration in renal cell carcinoma [160]. MiR-34a has anti-proliferative potentials causing down-regulation of several proliferative proteins including cyclin D1, cyclin E, CDK4 and CDK6 which induce cell cycle arrest in G0/G1 phase [161, 162]. Low P27 expression, a CDKs regulator which negatively controls cell cycle in transition of $\mathrm{G} 1$ to $\mathrm{S}$ phase by inhibiting cyclin E/CDK2 complex, is correlated with the expression of cyclin D1 in patients with renal cell carcinoma [163]. Decreased cyclin D1 levels leads to the release of p27 and induces cell cycle arrest. Metformin has previously shown its antitumor effect by reducing the regulation of cyclin D1 in AMPK-dependent mechanisms [164, 165].

\section{Skin cancer}

\section{MiR-21}

A study on skin keratinocyte cell line viability, suggested the involvement of miR-21/PTEN/Akt signaling pathway in anti-proliferative properties of metformin. Treatment of these cells with metformin leads to significant downregulation of miR-21 and up-regulation of PTEN which negatively modulate the AKT signaling pathway [166]. On the other hand, studies indicate a positive correlation between the expression of miR-21 and TGF- $\beta$. MiR21 exerts its effects on cell proliferation, migration and angiogenesis in keratinocytes as a downstream molecule of TGF- $\beta$ by activating TGF- $\beta$ signaling and targeting PTEN $[167,168]$. TGF- $\beta 1$ is involved in the progression of many diseases, including cancers [169]. Moreover, Metformin down-regulates miR-21 through antagonizing TGF- $\beta 1$ signaling by targeting mothers against decapentaplegic homolog 7 (SMAD7) protein and PTEN in an AMPK independent manner [91, 92]. In fact, metformin induces inhibitory effects on TGF- $\beta$-induced AKT-, SMAD- and ERK-dependent phosphorylation signaling pathways by down-regulation of miR-21[170].

\section{MiR-192-5 and miR-584-3}

Metformin up-regulates two other circulating miRs, miR-192-5p and miR-584-3p which function as tumor suppressors directly by binding to $3^{\prime} \mathrm{UTR}$ region of epidermal growth factor [171-173] containing fibulin-like extracellular matrix protein 1 (EFEMP1) and secretory carrier membrane proteins (SCAMP3), respectively, which play important roles in cell growth and motility. Tseng et al., have demonstrated that knocking EFEMP1 and SCAMP3 down, leads to cell cycle arrest in G2/M phase in human melanoma cell lines. On the other hand, cell invasion and migration were also affected by knocking EFEMP1 down [174-177].

\section{Conclusion}

In recent years, the role of miRs in diagnosis, prognosis and treatment of cancer has been greatly investigated and has opened a new avenue to understand distinct perspectives of cellular processes. Depending on their targets, miRs may have oncogenic or tumor-suppressive effects. Since metformin influences proliferation of cancer cells by modifying dysregulated miRs, their study may assist in elucidating the anticancer properties and mechanisms of metformin.

In this review, we have focused on the therapeutic role of metformin targeting miRs in different types of cancer. Studies investigating the role of metformin in different cancers may help clarify the link between metformin and downstream signaling pathways of related miRs. This may lead to finding new roles for metformin and related miRs as therapeutic molecules in curing cancer in the future.

Considering the safe profile of metformin and its low cost along with its anticancer properties involving 
regulation of various miRs in different types of cancers, metformin can be proposed as a novel therapeutic adjuvant to conventional chemotherapy regimens with the intention of enhancing outcome.

\section{Authors' contributions}

NA: literature survey, data gathering, writing and revising the manuscript. NF writing, editing and revising the manuscript. RF: data gathering, editing the manuscript. All authors read and approved the final manuscript.

\section{Funding}

None.

\section{Availability of data and materials}

Not applicable.

\section{Declarations}

Ethics approval and consent to participate:

Not applicable.

\section{Consent for publication}

Not applicable.

\section{Competing interests}

The authors declare no competing interests.

Received: 8 January 2021 Accepted: 7 April 2021

Published online: 13 April 2021

\section{References}

1. Hardie DG, Ross FA, Hawley SA. AMPK: a nutrient and energy sensor that maintains energy homeostasis. Nat Rev Mol Cell Biol. 2012:13(4):251-62.

2. Viollet B, Guigas B, Garcia NS, Leclerc J, Foretz M, Andreelli F. Cellular and molecular mechanisms of metformin: an overview. Clin Sci. 2012;122(6):253-70

3. Lei Y, Yi Y, Liu Y, Liu X, Keller ET, Qian C-N, et al. Metformin targets multiple signaling pathways in cancer. Chin J Cancer. 2017;36(1):1-9.

4. Kasznicki J, Sliwinska A, Drzewoski J. Metformin in cancer prevention and therapy. Ann Transl Med. 2014;2(6).

5. Re M, Magliulo G, Gioacchini FM, Bajraktari A, Bertini A, Çeka A, et al. Expression levels and clinical significance of miR-21-5p, miR-let-7a, and miR-34c-5p in laryngeal squamous cell carcinoma. BioMed Res Intern. 2017;1:1-9.

6. Do MT, Kim HG, Khanal T, Choi JH, Kim DH, Jeong TC, et al. Metformin inhibits heme oxygenase-1 expression in cancer cells through inactivation of Raf-ERK-Nrf2 signaling and AMPK-independent pathways. Toxicol Appl Pharmacol. 2013;271(2):229-38.

7. Sahra IB, Regazzetti C, Robert G, Laurent K, Le Marchand-Brustel $Y$, Auberger $P$, et al. Metformin, independent of AMPK, induces mTOR inhibition and cell-cycle arrest through REDD1. Can Res. 2011;71(13):4366-72.

8. Demirsoy IH, Ertural DY, Balci Ş, Çınkır Ü, Sezer K, Tamer L, et al. Profiles of circulating miRNAs following metformin treatment in patients with type 2 diabetes. J Med Biochem. 2018;37(4):499-506.

9. Valencia-Sanchez MA, Liu J, Hannon GJ, Parker R. Control of translation and mRNA degradation by miRNAs and siRNAs. Genes Dev. 2006;20(5):515-24.

10. Bartel DP. MicroRNAs: genomics, biogenesis, mechanism, and function. Cell. 2004;116(2):281-97.

11. Hayes J, Peruzzi PP, Lawler S. MicroRNAs in cancer: biomarkers, functions and therapy. Trends Mol Med. 2014;20(8):460-9.
12. Shen S, Sun Q, Liang Z, Cui X, Ren X, Chen H, et al. A prognostic model of triple-negative breast cancer based on miR-27b-3p and node status. PLOS ONE. 2014;9(6):e100664.

13. Jin L, Wessely O, Marcusson EG, Ivan C, Calin GA, Alahari SK. Prooncogenic factors miR-23b and miR-27b are regulated by Her2/Neu, EGF, and TNF-a in breast cancer. Can Res. 2013;73(9):2884-96.

14. Takahashi R-U, Miyazaki H, Takeshita F, Yamamoto Y, Minoura K, Ono $M$, et al. Loss of microRNA-27b contributes to breast cancer stem cell generation by activating ENPP1. Nat Commun. 2015;6:7318.

15. Ludovico O, Farina M, Copetti M, Palena A, Proto V, Marotta V, et al. ENPP1 mRNA levels in white blood cells and prediction of metformin efficacy in type 2 diabetic patients: a preliminary evidence. Nutr Metab Cardiovasc Dis. 2012;22(2):e5-6.

16. Pan J, Zhang Q, Wang Y, You M. 26 S proteasome activity is downregulated in lung cancer stem-like cells propagated in vitro. PLOS ONE. 2010;5(10):e13298.

17. Gao J, Liu Q-G. The role of miR-26 in tumors and normal tissues. Oncol Lett. 2011;2(6):1019-23.

18. Yang F-Q, Wang J-J, Yan J-S, Huang J-H, Li W, Che J-P, et al. Metformin inhibits cell growth by upregulating microRNA-26a in renal cancer cells. Int J Clin Exp Med. 2014;7(10):3289.

19. Yu T, Wang X-y, Gong R-g, Li A, Yang S, Cao Y-t, et al. The expression profile of microRNAs in a model of 7, 12-dimethyl-benz [a] anthranceinduced oral carcinogenesis in Syrian hamster. J Exp Clin Cancer Res. 2009;28(1):64

20. Deng M, Zhang R, He Z, Qiu Q, Lu X, Yin J, et al. TET-mediated sequestration of miR-26 drives EZH2 expression and gastric carcinogenesis. Can Res. 2017;77(22):6069-82.

21. Zhang B, Liu X-X, He J-R, Zhou C-X, Guo M, He M, et al. Pathologically decreased miR-26a antagonizes apoptosis and facilitates carcinogenesis by targeting MTDH and EZH2 in breast cancer. Carcinogenesis. 2011;32(1):2-9.

22. Chen C, Liu X, Chen C, Chen Q, Dong Y, Hou B. Clinical significance of let-7a-5p and miR-21-5p in patients with breast cancer. Ann Clin Lab Sci. 2019;49(3):302-8

23. Cabello P, Pineda B, Tormo E, Lluch A, Eroles P. The antitumor effect of metformin is mediated by miR-26a in breast cancer. Int J Mol Sci. 2016:17(8):1298.

24. Richardson AL, Wang ZC, De Nicolo A, Lu X, Brown M, Miron A, et al. X chromosomal abnormalities in basal-like human breast cancer. Cancer Cell. 2006;9(2):121-32.

25. Lee M, Oprea-llies G, Saavedra HI. Silencing of E2F3 suppresses tumor growth of Her2+ breast cancer cells by restricting mitosis. Oncotarget. 2015:6(35):37316.

26. Wang Y, Gao X, Wei F, Zhang X, Yu J, Zhao H, et al. Diagnostic and prognostic value of circulating miR-21 for cancer: a systematic review and meta-analysis. Gene. 2014;533(1):389-97.

27. Anwar SL, Sari DNI, Kartika Al, Fitria MS, Tanjung DS, Rakhmina D, et al. Upregulation of circulating MiR-21 expression as a potential biomarker for therapeutic monitoring and clinical outcome in breast cancer. Asian Pacific J Cancer Prevent APJCP. 2019;20(4):1223.

28. Pulito C, Mori F, Sacconi A, Goeman F, Ferraiuolo M, Pasanisi P, et al. Metformin-induced ablation of microRNA 21-5p releases Sestrin-1 and CAB39L antitumoral activities. Cell Discov. 2017;3(1):1-19.

29. Sharma P, Kumar S. Metformin inhibits human breast cancer cell growth by promoting apoptosis via a ROS-independent pathway involving mitochondrial dysfunction: pivotal role of superoxide dismutase (SOD). Cell Oncol. 2018;41(6):637-50.

30. Khalighfard S, Alizadeh AM, Irani S, Omranipour R. Plasma miR-21, miR155 , miR-10b, and Let-7a as the potential biomarkers for the monitoring of breast cancer patients. Sci Rep. 2018;8(1):1-11.

31. Kong W, He L, Coppola M, Guo J, Esposito NN, Coppola D, et al. MicroRNA-155 regulates cell survival, growth, and chemosensitivity by targeting FOXO3a in breast cancer. J Biol Chem. 2010;285(23):17869-79.

32. Liu X, Feng J, Tang L, Liao L, Xu Q, Zhu S. The regulation and function of miR-21-FOXO3a-miR-34b/c signaling in breast cancer. Int J Mol Sci. 2015;16(2):3148-62.

33. Queiroz EA, Puukila S, Eichler R, Sampaio SC, Forsyth HL, Lees SJ, et al. Metformin induces apoptosis and cell cycle arrest mediated by oxidative stress, AMPK and FOXO3a in MCF-7 breast cancer cells. PLOS ONE. 2014:9(5):e98207. 
34. Weiskopf K. Cancer immunotherapy targeting the CD47/SIRPa axis. Eur J Cancer. 2017;76:100-9.

35. Tan $W$, Tang H, Jiang X, Ye F, Huang L, Shi D, et al. Metformin mediates induction of miR-708 to inhibit self-renewal and chemoresistance of breast cancer stem cells through targeting CD47. J Cell Mol Med. 2019;23(9):5994-6004.

36. Antolín S, Calvo L, Blanco-Calvo M, Santiago MP, Lorenzo-Patiño MJ, Haz-Conde M, et al. Circulating miR-200c and miR-141 and outcomes in patients with breast cancer. BMC Cancer. 2015;15(1):1-15

37. Zhang J, Li G, Chen Y, Fang L, Guan C, Bai F, et al. Metformin inhibits tumorigenesis and tumor growth of breast cancer cells by upregulating miR-200c but downregulating AKT2 expression. J Cancer. 2017:8(10):1849

38. Lu J, Hang Q, Cui Y. Reduced serum miR-142-3p predicates worse prognosis in patients with cervical cancer. Int J Clin Exp Pathol. 2017;10(3):3637-43.

39. Xiao P, Liu W-L. MiR-142-3p functions as a potential tumor suppressor directly targeting HMGB1 in non-small-cell lung carcinoma. Int J Clin Exp Pathol. 2015;8(9):10800.

40. Xia C, Liang S, He Z, Zhu X, Chen R, Chen J. Metformin, a first-line drug for type 2 diabetes mellitus, disrupts the MALAT1/miR-142-3p sponge to decrease invasion and migration in cervical cancer cells. Eur J Pharmacol. 2018;830:59-67.

41. Ma C, Nong K, Zhu H, Wang W, Huang X, Yuan Z, et al. H19 promotes pancreatic cancer metastasis by derepressing let-7's suppression on its target HMGA2-mediated EMT. Tumor Biol. 2014;35(9):9163-9.

42. Park S-M, Shell S, Radjabi AR, Schickel R, Feig C, Boyerinas B, et al. Let-7 prevents early cancer progression by suppressing expression of the embryonic gene HMGA2. Cell Cycle. 2007;6(21):2585-90.

43. Wang W-Y, Cao Y-X, Zhou X, Wei B, Zhan L, Fu L-T. HMGA2 gene silencing reduces epithelial-mesenchymal transition and lymph node metastasis in cervical cancer through inhibiting the ATR/Chk1 signaling pathway. Am J Transl Res. 2018;10(10):3036.

44. Chandra Gupta S, Nandan TY. Potential of long non-coding RNAs in cancer patients: from biomarkers to therapeutic targets. Int J Cancer. 2017;140(9):1955-67.

45. Liu K, Huang J, Ni J, Song D, Ding M, Wang J, et al. MALAT1 promotes osteosarcoma development by regulation of HMGB1 via miR-142-3p and miR-129-5p. Cell Cycle. 2017;16(6):578-87.

46. Yang L, Bai H, Deng Y, Fan L. High MALAT1 expression predicts a poor prognosis of cervical cancer and promotes cancer cell growth and invasion. Eur Rev Med Pharmacol Sci. 2015:19(17):3187-93.

47. Yan L, Zhou J, Gao Y, Ghazal S, Lu L, Bellone S, et al. Regulation of tumor cell migration and invasion by the $\mathrm{H} 19 / \mathrm{let}-7$ axis is antagonized by metformin-induced DNA methylation. Oncogene. 2015;34(23):3076.

48. Fujimori T, Kato K, Fujihara S, Iwama H, Yamashita T, Kobayashi K, et al. Antitumor effect of metformin on cholangiocarcinoma: in vitro and in vivo studies. Oncol Rep. 2015;34(6):2987-96

49. Wandee J, Prawan A, Senggunprai L, Kongpetch S, Tusskorn O, Kukongviriyapan V. Metformin enhances cisplatin induced inhibition of cholangiocarcinoma cells via AMPK-mTOR pathway. Life Sci. 2018;207:172-83.

50. Masaki T, Shiratori Y, Rengifo W, Igarashi K, Yamagata M, Kurokohchi K, et al. Cyclins and cyclin-dependent kinases: comparative study of hepatocellular carcinoma versus cirrhosis. Hepatology. 2003;37(3):534-43.

51. Kato K, Gong J, Iwama H, Kitanaka A, Tani J, Miyoshi H, et al. The antidiabetic drug metformin inhibits gastric cancer cell proliferation in vitro and in vivo. Mol Cancer Ther. 2012:11(3):549-60.

52. Fujihara S, Kato K, Morishita A, Iwama H, Nishioka T, Chiyo T, et al. Antidiabetic drug metformin inhibits esophageal adenocarcinoma cell proliferation in vitro and in vivo. Int J Oncol. 2015;46(5):2172-80

53. Sahra IB, Laurent K, Loubat A, Giorgetti-Peraldi S, Colosetti P, Auberger $P$, et al. The antidiabetic drug metformin exerts an antitumoral effect in vitro and in vivo through a decrease of cyclin D1 level. Oncogene. 2008;27(25):3576.

54. Feng Y-H, Wu C-L, Shiau A-L, Lee J-C, Chang J-G, Lu P-J, et al. MicroRNA21-mediated regulation of Sprouty2 protein expression enhances the cytotoxic effect of 5-fluorouracil and metformin in colon cancer cells. Int J Mol Med. 2012;29(5):920-6.

55. Kim HJ, Bar-Sagi D. Modulation of signalling by Sprouty: a developing story. Nat Rev Mol Cell Biol. 2004:5(6):441-50.
56. Okugawa Y, Yao L, Toiyama Y, Yamamoto A, Shigemori T, Yin C, et al. Prognostic impact of sarcopenia and its correlation with circulating miR-21 in colorectal cancer patients. Oncol Rep. 2018;39(4):1555-64.

57. Sasaki A, Taketomi T, Kato R, Saeki K, Nonami A, Sasaki M, et al. Mammalian Sprouty4 suppresses Ras-independent ERK activation by binding to Raf1. Nat Cell Biol. 2003;5(5):427-32.

58. Lee C-C, Putnam AJ, Miranti CK, Gustafson M, Wang L-M, Woude GFV, et al. Overexpression of sprouty 2 inhibits HGF/SF-mediated cell growth, invasion, migration, and cytokinesis. Oncogene. 2004;23(30):5193-202.

59. Selcuklu SD, Donoghue MT, Spillane C. miR-21 as a key regulator of oncogenic processes. Biochem Soc Trans (Portland Press Ltd). 2009;37:918-25.

60. Minokoshi Y, Alquier T, Furukawa N, Kim Y-B, Lee A, Xue B, et al. AMPkinase regulates food intake by responding to hormonal and nutrient signals in the hypothalamus. Nature. 2004;428(6982):569-74.

61. Wang $Y, W u Z, H u L$. The regulatory effects of metformin on the [SNAIL/miR-34]:[ZEB/miR-200] system in the epithelial-mesenchymal transition (EMT) for colorectal cancer (CRC). Eur J Pharmacol. 2018:834:45-53.

62. Fan F, Samuel S, Evans KW, Lu J, Xia L, Zhou Y, et al. Overexpression of Snail induces epithelial-mesenchymal transition and a cancer stem cell-like phenotype in human colorectal cancer cells. Cancer Med. 2012;1(1):5-16.

63. Xiong H, Hong J, Du W, Lin Y-W, Ren L-I, Wang Y-c, et al. Roles of STAT3 and ZEB1 proteins in E-cadherin down-regulation and human colorectal cancer epithelial-mesenchymal transition. J Biol Chem. 2012;287(8):5819-32.

64. Pan Q, Meng L, Ye J, Wei X, Shang Y, Tian Y, et al. Transcriptional repression of miR-200 family members by Nanog in colon cancer cells induces epithelial-mesenchymal transition (EMT). Cancer Lett. 2017;392:26-38.

65. Shi X, Kaller M, Rokavec M, Kirchner T, Horst D, Hermeking H. Characterization of a p53/miR-34a/CSF1R/STAT3 feedback loop in colorectal cancer. Cell Mol Gastroenterol Hepatol. 2020;10(2):391-418.

66. Maierthaler M, Benner A, Hoffmeister M, Surowy H, Jansen L, Knebe $P$, et al. Plasma miR-122 and miR-200 family are prognostic markers in colorectal cancer. Int J Cancer. 2017;140(1):176-87.

67. Nugent M, Miller N, Kerin M. Circulating miR-34a levels are reduced in colorectal cancer. J Surg Oncol. 2012;106(8):947-52.

68. Nelson LE, Valentine RJ, Cacicedo JM, Gauthier M-S, Ido Y, Ruderman NB. A novel inverse relationship between metformin-triggered AMPK-SIRT1 signaling and p53 protein abundance in high glucoseexposed HepG2 cells. Am J Physiol Cell Physiol. 2012;303(1):C4-13.

69. Tian X-F, Ji F-J, Zang H-L, Cao H. Activation of the miR-34a/SIRT1/ p53 signaling pathway contributes to the progress of liver fibrosis via inducing apoptosis in hepatocytes but not in HSCs. PLoS ONE. 2016;11(7):e0158657.

70. Do MT, Kim HG, Choi JH, Jeong HG. Metformin induces microRNA34a to downregulate the Sirt1/Pgc-1 a/Nrf2 pathway, leading to increased susceptibility of wild-type p53 cancer cells to oxidative stress and therapeutic agents. Free Radical Biol Med. 2014;74:21-34.

71. Cufi S, Vazquez-Martin A, Oliveras-Ferraros C, Quirantes R, SeguraCarretero A, Micol V, et al. Metformin lowers the threshold for stress-induced senescence: a role for the microRNA-200 family and miR-205. Cell Cycle. 2012;11(6):1235-46.

72. Vang S, Wu H-T, Fischer A, Miller DH, MacLaughlan S, Douglass E, et al. Identification of ovarian cancer metastatic miRNAs. PLoS ONE. 2013;8(3):e58226.

73. Kato K, Iwama H, Yamashita T, Kobayashi K, Fujihara S, FuJIMORI T, et al. The anti-diabetic drug metformin inhibits pancreatic cancer cell proliferation in vitro and in vivo: study of the microRNAs associated with the antitumor effect of metformin. Oncol Rep. 2016;35(3):1582-92.

74. Noren Hooten N, Martin-Montalvo A, Dluzen DF, Zhang Y, Bernier $\mathrm{M}$, Zonderman $\mathrm{AB}$, et al. Metformin-mediated increase in DICER1 regulates microRNA expression and cellular senescence. Aging Cell. 2016;15(3):572-81.

75. McCarty MF. Metformin may antagonize Lin28 and/or Lin28B activity, thereby boosting let-7 levels and antagonizing cancer progression. Med Hypotheses. 2012;78(2):262-9. 
76. Zhong T, Men Y, Lu L, Geng T, Zhou J, Mitsuhashi A, et al. Metformin alters DNA methylation genome-wide via the $\mathrm{H} 19 / \mathrm{SAHH}$ axis. Oncogene. 2017;36(17):2345-54.

77. Ding XC, Weiler J, Großhans H. Regulating the regulators: mechanisms controlling the maturation of microRNAs. Trends Biotechnol. 2009;27(1):27-36.

78. Kallen AN, Zhou X-B, Xu J, Qiao C, Ma J, Yan L, et al. The imprinted H19 IncRNA antagonizes let-7 microRNAs. Mol Cell. 2013;52(1):101-12.

79. Yu J, Vodyanik MA, Smuga-Otto K, Antosiewicz-Bourget J, Frane JL, Tian $\mathrm{S}$, et al. Induced pluripotent stem cell lines derived from human somatic cells. Science. 2007;318(5858):1917-20.

80. King CE, Cuatrecasas M, Castells A, Sepulveda AR, Lee J-S, Rustgi AK. LIN28B promotes colon cancer progression and metastasis. Can Res. 2011;71(12):4260-8

81. Peng F, Li T-T, Wang K-L, Xiao G-Q, Wang J-H, Zhao H-D, et al. H19/let-7/ LIN28 reciprocal negative regulatory circuit promotes breast cancer stem cell maintenance. Cell Death Dis. 2018;8(1):e2569-e.

82. Heo I, Joo C, Cho J, Ha M, Han J, Kim VN. Lin28 mediates the terminal uridylation of let-7 precursor MicroRNA. Mol Cell. 2008;32(2):276-84.

83. Heo I, Joo C, Kim Y-K, Ha M, Yoon M-J, Cho J, et al. TUT4 in concert with Lin28 suppresses microRNA biogenesis through pre-microRNA uridylation. Cell. 2009;138(4):696-708.

84. Zhou J, Yang L, Zhong T, Mueller M, Men Y, Zhang N, et al. H19 IncRNA alters DNA methylation genome wide by regulating S-adenosylhomocysteine hydrolase. Nat Commun. 2015;6(1):1-13.

85. Guo M, Zhou JJ, Huang W. Metformin alleviates endometrial hyperplasia through the UCA1/miR-144/TGF- $31 /$ AKT signaling pathway. Int J Mol Med. 2020;45(2):623-33.

86. Wang W, Ge L, Xu X-J, Yang T, Yuan Y, Ma X-L, et al. LncRNA NEAT1 promotes endometrial cancer cell proliferation, migration and invasion by regulating the miR-144-3p/EZH2 axis. Radiol Oncol. 2019;53(4):434-42.

87. Piestrzeniewicz-Ulanska D, Brys M, Semczuk A, Rechberger T, Jakowicki JA, Krajewska WM. TGF- $\beta$ signaling is disrupted in endometrioid-type endometrial carcinomas. Gynecol Oncol. 2004;95(1):173-80.

88. Zuo Z-K, Gong Y, Chen X-H, Ye F, Yin Z-M, Gong Q-N, et al. TGFß1induced IncRNA UCA1 upregulation promotes gastric cancer invasion and migration. DNA Cell Biol. 2017;36(2):159-67.

89. Yamashita T, Kato K, Fujihara S, Iwama H, Morishita A, Yamana H, et al. Anti-diabetic drug metformin inhibits cell proliferation and tumor growth in gallbladder cancer via G0/G1 cell cycle arrest. Anticancer Drugs. 2020;31(3):231-40.

90. He D, Wang J, Zhang C, Shan B, Deng X, Li B, et al. Down-regulation of miR-675-5p contributes to tumor progression and development by targeting pro-tumorigenic GPR55 in non-small cell lung cancer. Mol Cancer. 2015;14(1):1-14

91. Xu Y, Liu Y, Li Z, Li H, Li X, Yan L, et al. Long non-coding RNA H19 is involved in sorafenib resistance in hepatocellular carcinoma by upregulating miR-675. Oncol Rep. 2020;44(1):165-73.

92. Saudy NS, Fawzy IM, Azmy E, Goda EF, Eneen A, Salam EMA. BMI1 gene expression in myeloid leukemias and its impact on prognosis. Blood Cells Mol Dis. 2014;53(4):194-8.

93. Li J, Wang Y, Ge J, Li W, Yin L, Zhao Z, et al. Doublecortin-like kinase 1 (DCLK1) regulates $B$ cell-specific moloney murine leukemia virus insertion site 1 (Bmi-1) and is associated with metastasis and prognosis in pancreatic cancer. Cell Physiol Biochem. 2018;51(1):262-77.

94. Guo B-H, Feng Y, Zhang R, Xu L-H, Li M-Z, Kung H-F, et al. Bmi-1 promotes invasion and metastasis, and its elevated expression is correlated with an advanced stage of breast cancer. Mol Cancer. 2011;10(1):10.

95. Huang K, Liu J, Li X, Song L-B, Zeng M-S. Association of Bmi-1 mRNA expression with differentiation, metastasis and prognosis of gastric carcinoma. Nan fang yi ke da xue xue bao. J Southern Med Univ. 2007;27(7):973-5

96. Huang D, He X, Zou J, Guo P, Jiang S, Lv N, et al. Negative regulation of Bmi-1 by AMPK and implication in cancer progression. Oncotarget. 2016;7(5):6188.

97. Chen Q, Ge X, Zhang Y, Xia H, Yuan D, Tang Q, et al. Plasma miR-122 and miR-192 as potential novel biomarkers for the early detection of distant metastasis of gastric cancer. Oncol Rep. 2014;31(4):1863-70.

98. Patel N, Garikapati KR, Ramaiah MJ, Polavarapu KK, Bhadra U, Bhadra MP. miR-15a/miR-16 induces mitochondrial dependent apoptosis in breast cancer cells by suppressing oncogene BMI1. Life Sci. 2016;164:60-70.
99. Koh H, Park H, Chandimali N, Huynh DL, Zhang JJ, Ghosh M, et al. MicroRNA-128 suppresses paclitaxel-resistant lung cancer by inhibiting MUC1-C and BMI-1 in cancer stem cells. Oncotarget. 2017;8(66):110540.

100. Zhou J, Yang Z, Tsuji T, Gong J, Xie J, Chen C, et al. LITAF and TNFSF15, two downstream targets of AMPK, exert inhibitory effects on tumor growth. Oncogene. 2011;30(16):1892-900.

101. Sun R, Ma X, Cai X, Pan X, Liu D. The effect and mechanism of action of metformin on in vitro FaDu cell proliferation. J Int Med Res. 2016:44(5):1049-54.

102. Liu J, Lei D-P, Jin T, Zhao X-N, Li G, Pan X-L. Altered expression of miR-21 and PTEN in human laryngeal and hypopharyngeal squamous cell carcinomas. Asian Pacific J Cancer Prevent APJCP. 2011;12(10):2653-7.

103. Ganci F, Sacconi A, Bossel Ben-Moshe N, Manciocco V, Sperduti I, Strigari $L$, et al. Expression of TP53 mutation-associated microRNAs predicts clinical outcome in head and neck squamous cell carcinoma patients. Ann Oncol. 2013;24(12):3082-8.

104. Lee S, Bang S, Song K, Lee I. Differential expression in normal-adenomacarcinoma sequence suggests complex molecular carcinogenesis in colon. Oncol Rep. 2006;16(4):747-54.

105. Jansen AP, Camalier CE, Stark C, Colburn NH. Characterization of programmed cell death 4 in multiple human cancers reveals a novel enhancer of drug sensitivity. Mol Cancer Ther. 2004;3(2):103-10.

106. Xu Y-T, Chen R-Q, Lin G-B, Fang X-L, Yu S-J, Liang X-H, et al. Defining the regulatory role of programmed cell death 4 in laryngeal squamous cell carcinoma. Biochem Cell Biol. 2018;96(5):522-38.

107. Dong J, Peng H, Yang X, Wu W, Zhao Y, Chen D, et al. Metformin mediated microRNA-7 upregulation inhibits growth, migration, and invasion of non-small cell lung cancer A549 cells. Anticancer Drugs. 2020;31(4):345.

108. Xiong S, Zheng Y, Jiang P, Liu R, Liu X, Chu Y. MicroRNA-7 inhibits the growth of human non-small cell lung cancer A549 cells through targeting BCL-2. Int J Biol Sci. 2011;7(6):805.

109. Zeng J, Cai S. Breviscapine suppresses the growth of non-small cell lung cancer by enhancing microRNA-7 expression. J Biosci. 2017;42(1):121-9.

110. Wang C, Ding M, Xia M, Chen S, Van Le A, Soto-Gil R, et al. A five-miRNA panel identified from a multicentric case-control study serves as a novel diagnostic tool for ethnically diverse non-small-cell lung cancer patients. EBioMedicine. 2015;2(10):1377-85.

111. Xiao H. MiR-7-5p suppresses tumor metastasis of non-small cell lung cancer by targeting NOVA2. Cell Mol Biol Lett. 2019;24(1):1-13.

112. Jin D, Guo J, Wu Y, Chen W, Du J, Yang L, et al. Metformin-repressed miR381-YAP-snail axis activity disrupts NSCLC growth and metastasis. J Exp Clin Cancer Res. 2020;39(1):1-24.

113. Jin D, Guo J, Wang D, Wu Y, Wang X, Gao Y, et al. The antineoplastic drug metformin downregulates YAP by interfering with IRF-1 binding to the YAP promoter in NSCLC. EBioMedicine. 2018;37:188-204.

114. Yu F-X, Zhao B, Guan K-L. Hippo pathway in organ size control, tissue homeostasis, and cancer. Cell. 2015;163(4):811-28.

115. Zhang Z, Li F, Tian Y, Cao L, Gao Q, Zhang C, et al. Metformin enhances the antitumor activity of CD8+ T lymphocytes via the AMPK-miR107-Eomes-PD-1 pathway. J Immunol. 2020;204(9):2575-88.

116. Rao RR, Li Q, Odunsi K, Shrikant PA. The mTOR kinase determines effector versus memory CD8+ T cell fate by regulating the expression of transcription factors T-bet and Eomesodermin. Immunity. 2010;32(1):67-78.

117. Zhao R, Song Y, Wang Y, Huang Y, Li Z, Cui Y, et al. PD-1/PD-L1 blockade rescue exhausted $C D 8+T$ cells in gastrointestinal stromal tumours via the PI3K/Akt/mTOR signalling pathway. Cell Prolif. 2019;52(3):e12571.

118. Xia H, Li Y, LV X. MicroRNA-107 inhibits tumor growth and metastasis by targeting the BDNF-mediated PI3K/AKT pathway in human non-small lung cancer. Int J Oncol. 2016;49(4):1325-33.

119. Bao X, Zhao L, Guan H, Li F. Inhibition of LCMR1 and ATG12 by demethylation-activated miR-570-3p is involved in the anti-metastasis effects of metformin on human osteosarcoma. Cell Death Dis. 2018;9(6):1-13.

120. Wang W, Sun J, Li F, Li R, Gu Y, Liu C, et al. A frequent somatic mutation in CD274 3'-UTR leads to protein over-expression in gastric cancer by disrupting miR-570 binding. Hum Mutat. 2012;33(3):480-4.

121. Guo W, Tan W, Liu S, Huang X, Lin J, Liang R, et al. MiR-570 inhibited the cell proliferation and invasion through directly targeting $\mathrm{B} 7-\mathrm{H} 1$ in hepatocellular carcinoma. Tumor Biol. 2015;36(11):9049-57. 
122. Zheng $H$, Zhang $L$, Zhao $Y$, Yang D, Song F, Wen $Y$, et al. Plasma miRNAs as diagnostic and prognostic biomarkers for ovarian cancer. PLOS ONE. 2013;8(11):e77853.

123. Yu Z, Wang Y, Wang B, Zhai J. Metformin Affects paclitaxel sensitivity of ovarian cancer cells through autophagy mediated by long noncoding RNASNHG7/miR-3127-5p axis. Cancer Biother Radiopharm. 2020.

124. Jiang J, Zhang Y, Guo Y, Yu C, Chen M, Li Z, et al. MicroRNA-3127 promotes cell proliferation and tumorigenicity in hepatocellular carcinoma by disrupting of PI3K/AKT negative regulation. Oncotarget 2015;6(8):6359.

125. Tang D, Zhao D, Wu Y, Yao R, Zhou L, Lu L, et al. The miR-3127-5p/p-STAT 3 axis up-regulates PD-L1 inducing chemoresistance in non-small-cell lung cancer. J Cell Mol Med. 2018;22(8):3847-56.

126. Schultz NA, Dehlendorff C, Jensen BV, Bjerregaard JK, Nielsen KR, Bojesen SE, et al. MicroRNA biomarkers in whole blood for detection of pancreatic cancer. JAMA. 2014;311(4):392-404.

127. Srivastava SK, Bhardwaj A, Singh S, Arora S, Wang B, Grizzle WE, et al. MicroRNA-150 directly targets MUC4 and suppresses growth and malignant behavior of pancreatic cancer cells. Carcinogenesis. 2011;32(12):1832-9.

128. Fa Z, Min Z, Tang J, Liu C, Yan G, Xi J. MicroRNA-150 suppresses the growth and malignant behavior of papillary thyroid carcinoma cells via downregulation of MUC4. Exp Ther Med. 2018;16(1):45-52.

129. Yang K, He M, Cai Z, Ni C, Deng J, Ta N, et al. A decrease in miR-150 regulates the malignancy of pancreatic cancer by targeting c-Myb and MUC4. Pancreas. 2015;44(3):370-9.

130. Farhana L, Dawson MI, Murshed F, Das JK, Rishi AK, Fontana JA. Upregulation of miR-150* and miR-630 induces apoptosis in pancreatic cancer cells by targeting IGF-1R. PLoS ONE. 2013;8(5):e61015.

131. Moser C, Schachtschneider P, Lang SA, Gaumann A, Mori A, Zimmermann J, et al. Inhibition of insulin-like growth factor-I receptor (IGF-IR) using NVP-AEW541, a small molecule kinase inhibitor, reduces orthotopic pancreatic cancer growth and angiogenesis. Eur J Cancer. 2008;44(11):1577-86.

132. Yue W, Zheng $X, L$ in $Y$, Yang CS, Xu Q, Carpizo D, et al. Metformin combined with aspirin significantly inhibit pancreatic cancer cell growth in vitro and in vivo by suppressing anti-apoptotic proteins $\mathrm{MCl}-1$ and Bcl-2. Oncotarget. 2015;6(25):21208.

133. Rozengurt E, Sinnett-Smith J, Kisfalvi K. Crosstalk between insulin/ insulin-like growth factor-1 receptors and $\mathrm{G}$ protein-coupled receptor signaling systems: a novel target for the antidiabetic drug metformin in pancreatic cancer. Clin Cancer Res. 2010;16(9):2505-11.

134. Kawanami T, Takiguchi S, Ikeda N, Funakoshi A. A humanized antiIGF-1R monoclonal antibody (R1507) and/or metformin enhance gemcitabine-induced apoptosis in pancreatic cancer cells. Oncol Rep. 2012;27(3):867-72.

135. Mannaerts GP, Van Veldhoven PP, Casteels M. Peroxisomal lipid degradation via $\beta$-and a-oxidation in mammals. Cell Biochem Biophys. 2000;32(1-3):73-87.

136. Ma M, Ma C, Li P, Ma C, Ping F, Li W, et al. Low glucose enhanced metformin's inhibitory effect on pancreatic cancer cells by suppressing glycolysis and inducing energy stress via up-regulation of miR-210-5p. Cell Cycle. 2020;19(17):2168-81.

137. Ni H-Z, Liu Z, Sun L-L, Zhou M, Liu C, Li W-D, et al. Metformin inhibits angiogenesis of endothelial progenitor cells via miR-221-mediated p27 expression and autophagy. Future Med Chem. 2019;11(17):2263-72.

138. Jiang X, Ma N, Wang D, Li F, He R, Li D, et al. Metformin inhibits tumor growth by regulating multiple miRNAs in human cholangiocarcinoma. Oncotarget. 2015;6(5):3178.

139. Kawaguchi T, Komatsu S, Ichikawa D, Morimura R, Tsujiura M, Konishi H, et al. Clinical impact of circulating miR-221 in plasma of patients with pancreatic cancer. Br J Cancer. 2013;108(2):361-9.

140. Sarkar S, Dubaybo H, Ali S, Goncalves P, Kollepara SL, Sethi S, et al. Down-regulation of miR-221 inhibits proliferation of pancreatic cancer cells through up-regulation of PTEN, p27kip1, p57kip2, and PUMA. Am J Cancer Res. 2013:3(5):465.

141. Tanaka R, Tomosugi M, Horinaka M, Sowa Y, Sakai T. Metformin causes G1-phase arrest via down-regulation of MiR-221 and enhances TRAIL sensitivity through DR5 up-regulation in pancreatic cancer cells. PLoS ONE. 2015;10(5):e0125779.
142. Coleman CB, Lightell DJ Jr, Moss SC, Bates M, Parrino PE, Woods TC. Elevation of miR-221 and-222 in the internal mammary arteries of diabetic subjects and normalization with metformin. Mol Cell Endocrinol. 2013;374(1-2):125-9.

143. Qian C, Ye Y, Mao H, Yao L, Sun X, Wang B, et al. Downregulated IncRNASNHG1 enhances autophagy and prevents cell death through the miR-221/222/p27/mTOR pathway in Parkinson's disease. Exp Cell Res. 2019;384(1):111614.

144. Li L, Wang Z, Hu X, Wan T, Wu H, Jiang W, et al. Human aortic smooth muscle cell-derived exosomal miR-221/222 inhibits autophagy via a PTEN/Akt signaling pathway in human umbilical vein endothelial cells. Biochem Biophys Res Commun. 2016;479(2):343-50.

145. Shankaraiah RC, Callegari E, Guerriero P, Rimessi A, Pinton P, Gramantieri $L$, et al. Metformin prevents liver tumourigenesis by attenuating fibrosis in a transgenic mouse model of hepatocellular carcinoma. Oncogene. 2019;38(45):7035-45

146. Li A, Omura N, Hong S-M, Vincent A, Walter K, Griffith M, et al. Pancreatic cancers epigenetically silence SIP1 and hypomethylate and overexpress miR-200a/200b in association with elevated circulating miR-200a and miR-200b levels. Can Res. 2010;70(13):5226-37.

147. Bai Z, Sun J, Wang X, Wang H, Pei H, Zhang Z. MicroRNA-153 is a prognostic marker and inhibits cell migration and invasion by targeting SNAI1 in human pancreatic ductal adenocarcinoma. Oncol Rep. 2015:34(2):595-602.

148. Sun Y, Zhang T, Wang C, Jin X, Jia C, Yu S, et al. MiRNA-615-5p functions as a tumor suppressor in pancreatic ductal adenocarcinoma by targeting AKT2. PLoS ONE. 2015;10(4):e0119783.

149. Yamana H, Kato K, Kobara H, Fujihara S, Fujita K, Namima D, et al. Metformin inhibits proliferation and tumor growth of QGP-1 pancreatic neuroendocrine tumor cells by inducing cell cycle arrest and apoptosis. Anticancer Res. 2020;40(1):121-32.

150. Yang J, Wei J, Wu Y, Wang Z, Guo Y, Lee P, et al. Metformin induces ER stress-dependent apoptosis through miR-708-5p/NNAT pathway in prostate cancer. Oncogenesis. 2015;4(6):e158-e.

151. Guo P, Lan J, Ge J, Nie Q, Mao Q, Qiu Y. miR-708 acts as a tumor suppressor in human glioblastoma cells. Oncol Rep. 2013;30(2):870-6.

152. Jang JS, Jeon H-S, Sun Z, Aubry MC, Tang H, Park C-H, et al. Increased miR-708 expression in NSCLC and its association with poor survival in lung adenocarcinoma from never smokers. Clin Cancer Res. 2012;18(13):3658-67.

153. McDonald AC, Vira M, Walter V, Shen J, Raman JD, Sanda MG, et al. Circulating microRNAs in plasma among men with low-grade and highgrade prostate cancer at prostate biopsy. Prostate. 2019;79(9):961-8.

154. Chen J, Gu Y, Shen W. MicroRNA-21 functions as an oncogene and promotes cell proliferation and invasion via TIMP3 in renal cancer. Eur Rev Med Pharmacol Sci. 2017;21(20):4566-76.

155. Kalogirou C, Schäfer D, Krebs M, Kurz F, Schneider A, Riedmiller H, et al. Metformin-derived growth inhibition in renal cell carcinoma depends on miR-21-mediated PTEN expression. Urol Int. 2016;96(1):106-15.

156. Aaltomaa S, Lipponen P, Ala-Opas M, Eskelinen M, Syrjänen K, Kosma V. Expression of cyclins A and D and p21 (waf1/cip1) proteins in renal cell cancer and their relation to clinicopathological variables and patient survival. Br J Cancer. 1999:80(12):2001-7.

157. Bera A, Ghosh-Choudhury N, Dey N, Das F, Kasinath BS, Abboud HE, et al. NFKB-mediated cyclin D1 expression by microRNA-21 influences renal cancer cell proliferation. Cell Signal. 2013;25(12):2575-86.

158. Connell-Crowley L, Harper JW, Goodrich DW. Cyclin D1/Cdk4 regulates retinoblastoma protein-mediated cell cycle arrest by site-specific phosphorylation. Mol Biol Cell. 1997;8(2):287-301.

159. Xie W, Wang L, Sheng H, Qiu J, Zhang D, Zhang L, et al. Metformin induces growth inhibition and cell cycle arrest by upregulating microRNA34a in renal cancer cells. Med Sci Monit Intern Med J Exp Clin Res. 2017;23:29

160. Yu G, Li H, Wang J, Gumireddy K, Li A, Yao W, et al. miRNA-34a suppresses cell proliferation and metastasis by targeting CD44 in human renal carcinoma cells. J Urol. 2014;192(4):1229-37.

161. Sun F, Fu H, Liu Q, Tie Y, Zhu J, Xing R, et al. Downregulation of CCND1 and CDK6 by miR-34a induces cell cycle arrest. FEBS Lett. 2008;582(10):1564-8.

162. Hermeking $\mathrm{H}$. The miR-34 family in cancer and apoptosis. Cell Death Differ. 2010;17(2):193-9. 
163. Migita T, Oda Y, Naito S, Tsuneyoshi M. Low expression of p27Kip1 is associated with tumor size and poor prognosis in patients with renal cell carcinoma. Cancer. 2002;94(4):973-9.

164. Zhou X, Kuang Y, Liang S, Wang L. Metformin inhibits cell proliferation in SKM-1 cells via AMPK-mediated cell cycle arrest. J Pharmacol Sci. 2019;141(4):146-52.

165. Zhuang Y, Miskimins W. Cell cycle arrest in Metformin treated breast cancer cells involves activation of AMPK, downregulation of cyclin D1, and requires p27 Kip1 or p21 Cip1. J Mol Signaling. 2008;3(1):1-11.

166. Deng Y, Ma W. Metformin inhibits HaCaT cell viability via the miR-21/ PTEN/Akt signaling pathway. Mol Med Rep. 2018;17(3):4062-6.

167. Wang J, Qiu Y, Shi N, Zhao J, Wang Y, Jiang H, et al. microRNA-21 mediates the TGF- $\beta 1$-induced migration of keratinocytes via targeting PTEN. Eur Rev Med Pharmacol Sci. 2016;20(18):3748-59.

168. Yang X, Wang J, Guo S-L, Fan K-J, Li J, Wang Y-L, et al. miR-21 promotes keratinocyte migration and re-epithelialization during wound healing Int J Biol Sci. 2011;7(5):685.

169. Xiao $H$, Zhang J, Xu Z, Feng $Y$, Zhang $M$, Liu J, et al. Metformin is a novel suppressor for transforming growth factor (TGF)- $\beta 1$. Sci Rep. 2016;6(1):1-9.

170. Luo M, Tan X, Mu L, Luo Y, Li R, Deng X, et al. MiRNA-21 mediates the antiangiogenic activity of metformin through targeting PTEN and SMAD7 expression and PI3K/AKT pathway. Sci Rep. 2017;7:43427.

171. Meyer B, Loeschke S, Schultze A, Weigel T, Sandkamp M, Goldmann T, et al. HMGA2 overexpression in non-small cell lung cancer. Mol Carcinog (Published in cooperation with the University of Texas MD Anderson Cancer Center). 2007:46(7):503-11.
172. Sheng Y, Qi S, Hu R, Zhao J, Rui W, Miao Y, et al. Identification of blood microRNA alterations in patients with severe active alopecia areata. J Cell Biochem. 2019;120(9):14421-30.

173. He X-W, Shi Y-H, Liu Y-S, Li G-F, Zhao R, Hu Y, et al. Increased plasma levels of miR-124-3p, miR-125b-5p and miR-192-5p are associated with outcomes in acute ischaemic stroke patients receiving thrombolysis. Atherosclerosis. 2019;289:36-43.

174. Chen G, Hu M, Qu X, Wang K, Qu Y. MicroRNA-584 directly targets CCND1 and inhibits cell proliferation and invasion in pancreatic cancer. Mol Med Rep. 2019;19(1):719-26.

175. Tseng H-W, Li S-C, Tsai K-W. Metformin treatment suppresses melanoma cell growth and motility through modulation of microRNA expression. Cancers. 2019;11(2):209.

176. Lei D, Zhang F, Yao D, Xiong N, Jiang X, Zhao H. MiR-338-5p suppresses proliferation, migration, invasion, and promote apoptosis of glioblastoma cells by directly targeting EFEMP1. Biomed Pharmacother. 2017:89:957-65.

177. Zhang $X$, Sheng J, Zhang $Y$, Tian $Y$, Zhu J, Luo N, et al. Overexpression of SCAMP3 is an indicator of poor prognosis in hepatocellular carcinoma. Oncotarget. 2017;8(65):109247.

\section{Publisher's Note}

Springer Nature remains neutral with regard to jurisdictional claims in published maps and institutional affiliations.
Ready to submit your research? Choose BMC and benefit from:

- fast, convenient online submission

- thorough peer review by experienced researchers in your field

- rapid publication on acceptance

- support for research data, including large and complex data types

- gold Open Access which fosters wider collaboration and increased citations

- maximum visibility for your research: over $100 \mathrm{M}$ website views per year

At BMC, research is always in progress.

Learn more biomedcentral.com/submissions 